D Edirisinghe, S Fernando and M Premathilake. The study was funded by a grant from the National Science Foundation, Sri Lanka.

\section{Conflicts of interest}

We declare that there are no conflicts of interest.

\section{References}

1. Andersson M, Takkouche B, Egli I, et al. Current global iodine status and progress over the last decade towards the elimination of iodine deficiency. Bull World Health Organ 2005; 83: 518-25.

2. Fernando MA, Balasuriya $\mathrm{S}$, Herath $\mathrm{KB}$, et al. Endemic Goitre in Sri Lanka. Asia Pac J Public Health 1989; 3:11-8.
3. Benett M. Ceylon and its Capabilities. National Archives in Sri Lanka. London W. M. H. Allen and Co: Laden Hall Street 1849: 856-60.

4. Wilson DC. Goitre in Ceylon and Nigeria. Br J Nutr 1954; 8: $90-9$.

5. Mahadeva K, Shanmuganathan SS. The problem of goitre in Ceylon. Br J Nutr 1967; 21: 341-52.

6. WHO, UNICEF, ICCIDD team. Assessment of Iodine deficiency disorders and monitoring their elimination. 2nd ed. WHO/NHD/01.1 2001: 36-40, 49-56.

7. Jayatissa R, Gunathilaka MM, Fernando DN. Iodine nutrition status among school children after salt iodisation. Ceylon Med J 2005; 50: 144-6.

8. Jayatissa R, Gunathilaka MM, Fernando DN. Iodine nutrition status among schoolchildren after salt iodisation. Ceylon Med J 2005; 50: 144-8.

\title{
Auxological outcome of growth hormone therapy at cessation of treatment in a cohort of growth hormone deficient Sri Lankan patients
}

\author{
K S H de Silva', M E C Muhandiram² \\ (Index words: growth hormone treatment, auxological outcome, Sri Lanka, growth hormone deficiency)
}

\begin{abstract}
Introduction Recombinant human growth hormone (r-hGH) for growth hormone deficiency (GHD) has been available free in the state hospitals of Sri Lanka since 2009.

Objectives The aims were to compare height standard deviation scores (SDS) before and after treatment and compare heights at final assessment in relation to the target height $(\mathrm{TH})$ and $\mathrm{TH}$ range

Method Patients with confirmed GHD followed up at the University Unit of the Lady Ridgeway Hospital, Colombo were studied. Anthropometric data were prospectively recorded from presentation to cessation of therapy. The height SDS before and after treatment were calculated and the heights at final assessment were compared with the $\mathrm{TH}$ and $\mathrm{TH}$ range.

Results Sixteen patients (15 boys) had completed treatment. The mean age at diagnosis was 145.38 $(S D=34.28)$ months with a mean skeletal age of 97.5 $(\mathrm{SD}=42.85)$ months. Mean ages at commencement was $164.75(S D=36.81)$ months and at cessation of therapy $212.06(\mathrm{SD}=30.12)$ months duration of therapy was 47.31 $(\mathrm{SD}=23.99)$ months.
\end{abstract}

Majority had isolated GHD and 8 patients had pituitary hypoplasia on neuro-imaging. The height SDS improved significantly with treatment from $-4.438(1.18)$ to -3.37 $(0.81), p<0.001$. When finally assessed at ages ranging from 15 years 10 months to 26 years 9 months, one patient had reached the $\mathrm{TH}$ while six were in the $\mathrm{TH}$ range.

Conclusions Auxological response to therapy was significant although treatment was started late due to financial constraints.

Ceylon Medical Journal 2015; 60: 44-8

\section{Introduction}

Recombinant human GH ( $\mathrm{r}-\mathrm{hGH}$ ) has been used in the treatment of children with growth hormone deficiency (GHD) since 1985 with a good safety profile [1,2,3]. Safety surveillance programme which included more than 60,000 children from 50 countries concluded that $\mathrm{r}-\mathrm{hGH}$ was a safe and effective replacement therapy [4].

Most of those diagnosed with GHD in Sri Lanka did not receive GH treatment until 2009 when it was made available free in state hospitals. This is the first report

Department of Paediatrics, Faculty of Medicine, University of Colombo, Sri Lanka.

Correspondence: KSHdeS, e-mail: <shamyadesilva@hotmail.com>. Received 12 November 2014 and revised version accepted 17 January 2015. 
from Sri Lanka based on the data from one unit at the Lady Ridgeway Hospital, Colombo, on the auxological outcome of therapy in a cohort of GH deficient patients treated with $\mathrm{r}-\mathrm{hGH}$. The objectives of the study were to compare height standard deviation scores (SDS) before and after treatment and heights at final assessment in relation to the target height $(\mathrm{TH})$ and target height range based on their parents' heights.

\section{Methods}

The study group consisted of GH deficient patients followed up in the University Paediatric Unit at the Lady Ridgeway Hospital, Colombo since 2005 who had completed GH therapy. They were initially referred for assessment of short stature which was confirmed according to the definition of the height being more than two standard deviations below the population mean or below the 3 rd percentile for age and sex $[3,5]$. They were examined at presentation and the relevant investigations were performed to exclude the presence of a chronic illness, skeletal and genetic disorders and other endocrine causes resulting in short stature [3]. Following the preliminary screening investigations including skeletal age, GHD was confirmed by a single provocation test using glucagon $[3,6]$. GHD was diagnosed when the peak stimulated GH using the ELISA technique, was less than $3.8 \mathrm{ng} / \mathrm{ml}(<10 \mathrm{mU} / \mathrm{l})$ and partial deficiency was defined as a peak stimulated level of 3.8 to $7.6 \mathrm{ng} / \mathrm{ml}(10-20 \mathrm{mU} / \mathrm{l})$ $[6,7,8]$. All had imaging of the hypothalamic-pituitary region prior to therapy [3]. They were treated with $\mathrm{r}-\mathrm{hGH}$ at an initial dose of $4.5 \mathrm{mg} / \mathrm{m}^{2} /$ week $[8,9]$ given by daily subcutaneous injections in the evening to simulate the normal physiology $[10,11]$. Dose adjustments were made periodically when indicated.

They were prospectively followed up and routine examinations and regular anthropometric measurements were carried out by one investigator and biochemical and radiological investigations were performed when indicated until cessation of therapy. The heights were measured using a wall mounted stadiometer. Treatment was discontinued at a predetermined skeletal age or when puberty was established or at the patient's and or parents' request [8].

The patients' pre and post treatment height standard deviation scores (SDS) were calculated using the LMS growth programme version 2.69 (2010) using WHO Child and 5-19 growth reference standards (2006/2007). The significance of these findings was determined using the paired $t$ test.

The target height $(\mathrm{TH})$ or mid-parental height for each patient was calculated based on their parents' heights and the $\mathrm{TH}$ range was arrived at using the following formulae [12]. Target height for girls $=$ Mother's height + father's height $-13 \mathrm{~cm} \div 2$. Target height for boys $=$ Mother's height + father's height $+13 \mathrm{~cm} \div 2$. Target height range $=\mathrm{TH} \pm 8.5 \mathrm{~cm}$.
The heights of the patients at final assessment were compared with the $\mathrm{TH}$ and $\mathrm{TH}$ range thus calculated to determine the auxological outcome of therapy.

Ethics clearence was obtained from the Ethics Review Committee of the Faculty of Medicine, Colombo. Written informed consent was obtained from parents.

\section{Results}

Sixteen patients (15 boys) completed treatment. Duration of treatment ranged from 16 to 95 months with a mean of $47.31(\mathrm{SD}=23.99)$ months. Age at diagnosis ranged from 77 to 199 months [mean145.38 $(\mathrm{SD}=34.28)$ months]. Age at starting treatment ranged from 110 months to 257 months, [mean of 164.75 (SD = 36.81) months]. Age at cessation of therapy ranged from 173 months to 293 months [mean of $212.06(\mathrm{SD}=30.12)$ months]. Mean skeletal age prior to treatment was 97.5 $(\mathrm{SD}=42.85)$ months and range was 24 to 168 months. Mean height at commencement was $124.98 \mathrm{~cm}$ (SD $=11.79)$ and at cessation of therapy $149.16 \mathrm{~cm}(\mathrm{SD}=5.63)$ and this difference was statistically significant $(\mathrm{t}=8.78, \mathrm{df}$ $=15, \mathrm{p}<0.001$ ).

Of the 16 patients, 9 were deficient in $\mathrm{GH}$ on provocative testing while others showed a partial deficiency. One patient each had deficiency of TSH and ACTH initially and subsequently during follow up, six developed deficiency of TSH, and one also had associated ACTH deficiency. The gonadotrophin levels prior to treatment were not assessed as the appropriate stimulation test could not be performed. Subsequently all the boys went into puberty naturally whereas the girls needed hormone replacement therapy. Hypoplasia of the pituitary gland was seen in eight patients on neuro-imaging while the posterior pituitary gland was not affected in any of them.

Treatment with $\mathrm{r}-\mathrm{hGH}$ resulted in a significant increase in the height SDS at cessation of therapy: -4.438 (1.18) to -3.37 (0.81), $p<0.001$ (Table 1). The height velocity during the first year of therapy ranged from $5 \mathrm{~cm}$ to $12.2 \mathrm{~cm}$, mean $7.99(\mathrm{SD}=2.12)$ and the increment in height observed was $7.2 \mathrm{~cm}$ to $43.5 \mathrm{~cm}$ with 10 patients gaining $25 \mathrm{~cm}$ at the end of treatment (Table 1). Their ages at final assessment ranged from 15 years 10 months to 26 years 9 months, mean $232(\mathrm{SD}+32.37)$ months. Although only one patient had reached the $\mathrm{TH}$, six were within the TH range (Table 2). None of the patients experienced any complications of therapy.

\section{Discussion}

GH was first isolated from human cadaveric pituitary glands in 1956 and the pituitary derived GH was used for the first time on a child with GHD by Maury Raben in $1958[10,11,13,14]$. Use of this preparation was suspended in 1985 due to concerns about the association with Creutzfeldt-Jakob disease with pituitary derived 
Table 1. Outcome of treatment on heights of patients

\begin{tabular}{|c|c|c|c|c|c|c|}
\hline Gender & $\begin{array}{l}\text { Pre treatment } \\
\text { height }(\mathrm{cm})\end{array}$ & $\begin{array}{c}\text { Pre treatment } \\
\text { height SDS }\end{array}$ & $\begin{array}{l}\text { Post treatment } \\
\text { height }(\mathrm{cm})\end{array}$ & $\begin{array}{l}\text { Post treatment } \\
\text { height SDS }\end{array}$ & $\begin{array}{l}\text { Height velocity } \\
\text { during the } 1^{\text {st }} \\
\text { year of treatment } \\
\mathrm{cm} / \text { year }\end{array}$ & $\begin{array}{l}\text { Increment in } \\
\text { height with } \\
\text { treatment } \\
\quad(\mathrm{cm})\end{array}$ \\
\hline 1 Male & 109.1 & -4.27 & 152.6 & -3.27 & 10.3 & 43.5 \\
\hline 2 Male & 118.0 & -4.78 & 144.0 & -4.43 & 9.0 & 26.0 \\
\hline 3 Male & 119.5 & -4.01 & 158.5 & -2.70 & 9.0 & 39.0 \\
\hline 4 Male & 117.0 & -5.39 & 143.0 & -4.91 & 7.8 & 26.0 \\
\hline 5 Male & 130.0 & -3.70 & 147.3 & -3.06 & 9.2 & 17.3 \\
\hline 6 Male & 145.0 & -2.73 & 155.0 & -2.61 & 6.0 & 10.0 \\
\hline 7 Male & 141.1 & -5.29 & 153.5 & $-3.42 *$ & 7.5 & 12.4 \\
\hline 8 Male & 113.0 & -3.61 & 142.5 & -2.75 & 5.0 & 29.5 \\
\hline 9 Male & 118.8 & -3.80 & 148.0 & -3.34 & 8.4 & 29.2 \\
\hline 10 Male & 125.2 & -3.02 & 152.0 & -2.15 & 8.0 & 26.8 \\
\hline 11 Male & 113.5 & -7.00 & 141.1 & -5.19 & 11.3 & 27.6 \\
\hline 12 Male & 126.8 & -3.18 & 143.0 & -2.90 & 5.3 & 16.2 \\
\hline 13 Male & 113.7 & -5.24 & 153.5 & -3.40 & 6.3 & 39.8 \\
\hline 14 Male & 147.0 & -3.86 & 154.2 & -3.27 & 6.0 & 7.2 \\
\hline 15 Male & 129.5 & -6.14 & 154.5 & -3.27 & 12.2 & 25.0 \\
\hline 16 Female & 132.6 & -5.00 & 144.0 & -3.25 & 6.5 & 11.4 \\
\hline Mean (SD) & 124.98 (11.79) & $-4.438(1.18)$ & $149.16(5.63)$ & $-3.37(0.81)$ & 7.99 (2.12) & 24.18 (11.01) \\
\hline
\end{tabular}

Statistical significance of the pre and post treatment height $\operatorname{SDS} \circledast \mathrm{t}=\mathbf{5 . 5 7}, \mathrm{df}=15, p=0.000$

* Number 7 taken as 20 years as the LMS growth programme version 2.69 (2010) does not allow analysis after 20 years. [If number 7 was not taken for analysis - post treatment height SDS, mean (SD) $\left.{ }^{\circledR}-3.36(0.84)\right]$

Table 2. Patients' heights at final assessment in relation to the parents' heights

\begin{tabular}{lcccccc}
\hline Gender & $\begin{array}{c}\text { Age at final } \\
\text { assessment }\end{array}$ & $\begin{array}{c}\text { Fathers'height } \\
(\mathrm{cm})\end{array}$ & $\begin{array}{c}\text { Mothers'height } \\
(\mathrm{cm})\end{array}$ & $\begin{array}{c}\text { Height at final } \\
\text { assessment }(\mathrm{cm})\end{array}$ & $\begin{array}{c}\text { Target height } \\
\text { range }(\mathrm{cm})\end{array}$ & $\begin{array}{c}\text { Target height } \\
(\mathrm{cm})\end{array}$ \\
\hline 1 Male & $18 \mathrm{yrs} 4 \mathrm{~m}$ & 167.0 & 152.0 & 154.0 & $157.5-174.5$ & 166.0 \\
2 Male & $18 \mathrm{yrs} 5 \mathrm{~m}$ & 167.5 & 153.0 & 145.5 & $158.3-175.3$ & 166.8 \\
3 Male & $21 \mathrm{yrs} 1 \mathrm{~m}$ & 166.5 & 162.0 & 160.1 & $162.3-179.3$ & 170.8 \\
4 Male & $20 \mathrm{yrs} 3 \mathrm{~m}$ & 182.0 & 152.0 & 145.5 & $165.0-182.0$ & 173.5 \\
5 Male & $16 \mathrm{yrs} 10 \mathrm{~m}$ & 169.0 & 161.5 & 155.5 & $163.3-180.3$ & 171.8 \\
6 Male & $17 \mathrm{yrs} 6 \mathrm{~m}$ & 162.0 & 163.0 & 160.8 & $\mathbf{1 6 0 . 5 - 1 7 7 . 5}$ & 169.0 \\
7 Male & $26 \mathrm{yrs} 9 \mathrm{~m}$ & 157.0 & 152.0 & 156.0 & $\mathbf{1 5 2 . 5}-1 \mathbf{1 6 9 . 5}$ & 161.0 \\
8 Male & $15 \mathrm{yrs} 10 \mathrm{~m}$ & 157.0 & 142.0 & 150.0 & $\mathbf{1 4 7 . 5 - 1 6 4 . 5}$ & 156.0 \\
9 Male & $17 \mathrm{yrs} 3 \mathrm{~m}$ & 170.0 & 150.0 & 149.3 & $158.0-175.0$ & 166.5 \\
10 Male & $16 \mathrm{yrs} 6 \mathrm{~m}$ & 175.0 & 152.0 & 158.0 & $161.5-178.5$ & 170.0 \\
11 Male & $20 \mathrm{yrs} 9 \mathrm{~m}$ & 147.0 & 145.0 & 145.1 & $\mathbf{1 4 4 . 0 - 1 6 1 . 0}$ & 152.5 \\
12 Male & $17 \mathrm{yrs} 7 \mathrm{~m}$ & 166.0 & 150.5 & 151.0 & $156.3-173.3$ & 164.8 \\
13 Male & $20 \mathrm{yrs} 10 \mathrm{~m}$ & 167.0 & 160.0 & 157.0 & $161.5-178.5$ & 170.0 \\
14 Male & $20 \mathrm{yrs} 8 \mathrm{~m}$ & 160.0 & 156.0 & $\mathbf{1 6 5 . 5}$ & $\mathbf{1 5 6 . 0 - 1 7 3 . 0}$ & $\mathbf{1 6 4 . 5}$ \\
15 Male & $19 \mathrm{yrs} 2 \mathrm{~m}$ & 162.0 & 150.0 & 154.5 & $\mathbf{1 5 4 . 0 - 1 7 1 . 0}$ & 162.5 \\
16 Female & $21 \mathrm{yrs} 7 \mathrm{~m}$ & 167.0 & 148.0 & 145.8 & $\mathbf{1 4 2 . 5 - 1 5 9 . 5}$ & 151.0 \\
\hline & & & & &
\end{tabular}


$\mathrm{GH}[2,11]$. Identification of the biochemical structure of GH in 1972 and progress in molecular biology prompted the process of manufacturing a recombinant human $\mathrm{GH}$ preparation in 1981 and in 1985 this product was approved for use in GHD [10, 11]. Since then r-hGH has been used for several conditions other than GHD $[1,10,11]$. GH is not essential for life but it is essential for linear growth. If deficient and not treated the very short child will grow up to be an extremely short adult (125 to $130 \mathrm{~cm}$ ) as GH accounts for approximately $38 \mathrm{~cm}$ of post natal growth in boys and $33 \mathrm{~cm}$ in girls [15].

Presence of GHD in Sri Lankan children was first documented in 1991 [16]. Following a meticulous screening and diagnostic process and based on TannerWhitehouse standards a prevalence of 1:1300 for GHD was reported $[5,16]$. A more recent publication describes the outcome of r-hGH treatment after a mean duration of 17.6 months in 21 adolescents with conditions including GHD, Turner syndrome and Prader-Willi syndrome [17].We reported the psychological status of children with GHD and their parents in 2011 [18]. Forty children with GHD (including 13 in the present study) were assessed using the Perso-nality Assessment Questionnaire (PAQ) administered prior to treatment. Psychological maladjustment was observed in $24(60 \%)$ and $54 \%$ of the parents were similarly affected as measured by the General Health Questionnaire-30 (GHQ-30).

To obtain the best auxological outcome of $\mathrm{GH}$ therapy, treatment should be started as early as possible, as younger the age of starting treatment, better the outcome [3, 9]. Most children would reach their genetic potential with $\mathrm{GH}$ therapy, but the response is variable and some patients fail to achieve their potential especially when treatment is started at an older age $[2,19]$. In our cohort, treatment resulted in only seven patients $(43.8 \%)$ reaching the $\mathrm{TH} / \mathrm{TH}$ range. Our patients presented late as they were diagnosed at a mean age of 145.38 months and treatment was started at mean age of 164.75 months due to financial constraints. The increment may have been greater if they had presented earlier and were treated at a younger age.

Six of our patients purchased GH initially but due to the expense it was not given regularly. The monthly income of these families ranged from Rs 10,000.00 to $60,000.00$ with only two families earning Rs 50,000.00 a month. Therefore it was not affordable for most of the parents until it was available free in 2009. Optimal treatment during the first two years of therapy is crucial to achieve the best outcome [19]. But the supply of GH was not always continuous and therefore the treatment was intermittent at times which may have contributed to the final outcome in our patients.

Although not formerly assessed, all of them were happy with the outcome of therapy and the psychological benefit appeared to be immense. More patients in our cohort could have reached the $\mathrm{TH} / \mathrm{TH}$ range thus improving their auxological outcome if they could have commenced treatment at a younger age and the availability of GH was continuous. We did not reassess the secretory status of GH after stopping treatment to identify those likely to benefit from continuing GH therapy as adults $[1,3,9]$. Once treatment was completed they were referred to adult endocrine services for follow up.

\section{Acknowledgement}

We acknowledge Dr. Meliyanthi Gunatillaka, Consultant Chemical Pathologist, formerly of the Medical Research Institute (MRI) for her pioneering efforts to establish serum growth hormone and cortisol assays along with assay of several other steroids, at the MRI. Almost all the investigations in our patients were done free at this institution.

\section{Conflicts of interest}

We declare that there are no conflicts of interest.

\section{References}

1. Wilson TA, Rose SR, Cohen P, et al. Update of guidelines for the use of growth hormone in children: The Lawson Wilkins Pediatric Endocrinology Society Drug and Therapeutics Committee. J Pediatr 2003, 143: 415-21.

2. Guidelines for the use of growth hormone in children with short stature. A report by the Drug and Therapeutics Committee of the Lawson Wilkins Pediatric Endocrine Society. J Pediatr 1995; 127: 857-67.

3. Consensus Guidelines for the Diagnosis and Treatment of Growth Hormone (GH) Deficiency in Childhood and Adolescence: Summary Statement of the GH Research Society. J Clin Endocrinol Metab 2000; 85: 3990-93.

4. Ranke MB, Price DA, Reiter EO (eds): Growth Hormone Therapy in Pediatrics-20 years of KIGS. Basel, Karger, 2007.

5. Tanner JM, Whitehouse RH. Clinical longitudinal standards for height, weight, height velocity, weight velocity and stages of puberty. Arch Dis Child 1976; 51: 170-9.

6. Stanley Takara. Diagnosis of Growth Hormone Deficiency in Childhood. Curr Opin Endocrinol Diabetes Obes 2012; 19: $47-52$

7. College of Pathologists of Sri Lanka: National Guidelines in Chemical Pathology 2007. Ministry of Healthcare and Nutrition.

8. Guidelines for the Availability of Human Growth Hormone $(\mathrm{hGH})$ as a Pharmaceutical Benefit. Commonwealth Department of Health and Ageing 2004,1-16.

9. Gopal-Kothandapani Jaya Sujatha, Banerjee Indraneel, Patel Leena. Growth: importance and implications of variations. In: Practical Paediatric Endocrinology in a Limited Resource Setting $1^{\text {st }}$ edition 2011, 1-23. Editor Margaret Zacharin. Merck Serono, Melbourne, Australia.

10. Ayyar Vageesh S. History of growth hormone therapy. Indian J Endocrinol Metab 2011; 15: S162-S165.

11. Krysiak R, Gdula-Dymek A, Bednarska-Czerwinska A, Okopien B. Growth hormone therapy in children and adults. Pharmacol Rep 2007; 59: 500-16. 
12. Tanner JM, Goldstein H, Whitehouse RH. Standards for children's height at ages 2-9 years allowing for height of parents. Arch Dis Child 1970; 45: 755-62.

13. Raben MS. Treatment of a pituitary dwarf with human growth hormone. J Clin Endocrinol Metab 1958; 18: 901-3.

14. Ranke Michael B, Lindberg Anders. Observed and Predicted Growth Responses in Prepubertal Children with Growth Disorders: Guidance of Growth Hormone Treatment by Empirical Variables. J Clin Endocrinol Metab 2010; 95:1229-37.

15. Cowell CT. Short stature. In: Clinical Paediatric Endocrinology $3^{\text {rd }}$ edition 1995, 136-172. Edited by Charles G.D. Brook. Blackwell Science Ltd. University Press, Cambridge.
16. de Mel T, Warnasooriya N, Fonseka C. Growth hormone deficiency in Sri Lanka: a preliminary study. Ceylon Med $J$ 1991; 36: 95-7.

17. Gamage KKK, Mangaleswaran S, Galappaththy SAL, et al. Growth hormone therapy for short stature in adolescents - the experience in the University Medical Unit, National Hospital of Sri Lanka. Sri Lanka J Diabetes, Endocrinol Metab 2014; 4: 49-55.

18. de Silva KSH, de Zoysa P. Assessment of the psychological status of children with growth hormone deficiency and their parents. Ceylon Med J 2011; 56: 59-61.

19. Bajpai Anurag, Kabra Madhulika, Gupta Arun Kumar, Menon PSN. Growth Pattern and Skeletal Maturation Following Growth Hormone Therapy in Growth Hormone Deficiency: Factors Influencing Outcome. Indian Pediatr 2006; 43: 593-99. 